Research article

\title{
Austrian teachers' understanding and teaching of historical culture: challenges for the implementation of curriculum reforms in Austria
}

\author{
Andrea Brait iD \\ University of Innsbruck, Austria \\ Correspondence: andrea.brait@uibk.ac.at
}

Submission date: 15 January 2021; Acceptance date: 8 April 2021; Publication date: 27 January 2022

\section{How to cite}

Brait, A. (2022) 'Austrian teachers' understanding and teaching of historical culture: challenges for the implementation of curriculum reforms in Austria'. History Education Research Journal, 19 (1), 1-13. DOI: https://doi.org/10.14324/HERJ.19.1.01.

\section{Peer review}

This article has been peer-reviewed through the journal's standard double-blind peer review, where both the reviewers and authors are anonymised during review.

\section{Copyright}

2022, Andrea Brait. This is an open-access article distributed under the terms of the Creative Commons Attribution Licence (CC BY) 4.0 https://creativecommons.org/licenses/by/4.0/, which permits unrestricted use, distribution and reproduction in any medium, provided the original author and source are credited $\bullet$ DOI: https://doi.org/10.14324/HERJ.19.1.01.

\section{Open access}

The History Education Research Journal is a peer-reviewed open-access journal.

\begin{abstract}
In Austria, there have been repeated reforms of history curricula in recent years. In particular, these reforms have had the goal of implementing competence orientation. However, numerous research studies have shown that history teachers find it difficult to implement the new standards and that they only partially incorporate the central theoretical principles of the curricula into their teaching practice. In addition, the new specifications have not been fully incorporated into textbooks. This article focuses specifically on the inclusion of historical representations in the classroom, and on the opinions of history teachers in relation to this. Since Austrian curricula are committed to a critical approach towards historical culture, in addition to a source-based approach, the inclusion of historical representations is necessary in order to meet state requirements. However, based on 85 qualitative interviews with Austrian history teachers, it is evident that these teachers are only partially familiar with the theories of history didactics. Many history teachers are not informed about the technical terms used in the curricula, and when manifestations of historical culture are considered in history lessons, they are rarely critically examined.
\end{abstract}

Keywords curriculum reforms; historical culture; historical representations; history teachers; competences; FUER; Austria; high schools 


\section{Competence-oriented curricula for history teaching in Austria}

State curricula have existed in Austria since about the middle of the nineteenth century. Since the beginning of the twentieth century, these have been developed mostly in commissions involving teachers, social scientists, subject specialists, education experts and representatives of school administrations; this became common practice after 1945 (Wiater, 2009). The contents and goals of curricula can be seen as a 'lowest common denominator' of different social interests. The adoption is usually preceded by in-depth educational policy debates (Hacker, 1999).

In Austria, the school system has traditionally been organised in a centralised way, starting with Maria Theresa's reforms in the eighteenth century (Eder and Thonhauser, 2017). This means that the same curricula for each school type are valid for the entire federal territory. After four years of primary school (which is attended from the age of 6), all students attend four school grades of junior high school (fifth to eighth grade) in two different school types ('Mittelschule' and 'Unterstufe Gymnasium'), which have the same curriculum. After that, students can choose between different types of schools with different curricula. Some attend senior high schools ('Oberstufe Gymnasium'), which end after the twelfth grade with final examinations ('Matura'), which are the general qualifications for university entrance. History is taught from the sixth grade (which is usually attended from the age of 11) onwards.

The curricula for history have been reformed several times. In the last twenty years, reforms of the curricula for all subjects have been influenced in particular by the developments that followed the socalled 'PISA shock' (Bozkurt et al., 2007; Lucyshyn, 2013). These tests demonstrated deficits, especially in transferring and applying what had been learned to unknown cases (Germ, 2015). In Austria, competenceoriented curricula (BGBI., 2008) for history education were introduced in 2008, and they were gradually combined with the subject area of civic education (Zeilner, 2011). These were intended to put an end to the predominant content orientation of teaching (Ammerer, 2009). The curricula use the definition from Franz E. Weinert (2001), according to which competences are to be described as the cognitive abilities and skills available in, or learnable by, individuals to solve specific problems, as well as the associated motivational, volitional and social dispositions and abilities to apply the solutions to problems successfully and responsibly in variable situations. The aim was thus to move away from the previous concentration on teaching factual historical knowledge (Kühberger, 2012), that is, the teaching of historical events, dates and people.

The four competences, based on the FUER (Förderung und Entwicklung von reflektiertem und (selbst-)reflexivem Geschichtsbewusstsein) competence model (Körber et al., 2007), were briefly explained in the general part of the subject curriculum with one paragraph each. Students should be enabled to ask questions about the past and to identify existing questions in historical narratives (inquiring competence). They should learn to deal with historical sources with the purpose of telling history, as well as to deal critically with historical narratives in films, exhibitions and so on (methodical competence). Furthermore, it was noted that the terms and concepts for describing factual knowledge should be concretised and further developed (subject matter competence). Finally, it was stated that historical learning should contribute to a better understanding of contemporary phenomena and future challenges (orientation competence) (BGBI., 2008).

However, it became apparent that for a long time the change in teaching practice from content orientation to competence orientation, which was postulated by the curriculum reform, rarely took place in practice. In his 2014 survey of 89 history teachers who taught at high schools in the province of Carinthia, Christian Pichler (2016) shows, among other things, that the majority of them did not consider working with sources and historical representations, or the development of methodological competence, to be central, which was explained by a lack of time. More than ten years after the FUER competence model was first implemented, many history teachers are still unfamiliar with it, as Roland Bernhard (2019b) documents in his study. The work of Kipman and Kühberger (2019) similarly suggests that most history teachers do not yet develop the orientation competence in classrooms. For example, 61.7 per cent of the 
277 teachers from three federal states surveyed in their study stated that subject-specific competence orientation was 'important' or 'very important', but 68.7 per cent of the respondents conceded that they had not yet become fully familiar with it (Kipman and Kühberger, 2019: 89-90).

A further insight into the practical realisation of subject-specific competence orientation in Austrian history teaching can be found in analyses of state-approved textbooks, which are undoubtedly regarded as an important factor in the implementation of curricular requirements (Popp, 2008). A wide range of such analyses are already available, and they clearly show that competence orientation has only been partially implemented (Bernhard, 2016; Eigler and Kühberger, 2018; Mittnik, 2018; Bramann, 2019; Buchberger, 2020).

Further evidence about the implementation of subject-specific competence orientation is provided by studies focusing on the final examinations at senior high school. In his qualitative study of these final examinations, Oberhauser (2018) showed that although the general requirements of the Matura test (for example, material basis) are fulfilled, teachers are either not familiar with the theoretical basis - specifically, the FUER competence model - or they fundamentally reject such an approach. In a quantitative study of the final examinations for the 2014/15 school year, Mittnik (2014) showed that 776 tasks (68.12 per cent) did not contain any competence-oriented aspects. It is, therefore, not surprising that in his study of final examinations at senior high schools in Carinthia in 2015, Pichler (2020) found that, in most cases, students only reached a competence level which, according to the FUER targets, should already be achieved at the end of junior high school, and that the testing of factual knowledge was more evident than competences in the oral examinations.

Thus, various studies have clearly shown that the central theoretical foundations of the curricula have not yet been consistently integrated into teaching practice by Austrian history teachers. The conditions for further curriculum reforms were, therefore, anything but favourable. Nevertheless, such curricula, influenced by the recent discourse of history didactics, were introduced in 2016 for junior high schools (BGBI., 2016a) and senior high schools (BGBI., 2016b). In addition to the introduction of conceptual learning, modularisation and a partial shift away from the chronological approach, it is particularly noticeable that there is no longer just a general reference to the FUER competence model, but that it is specified exactly which sub-competences are to be promoted. In addition to information on topics to be taught, there is now explicit mention of manifestations of historical culture. For example, in the first learning year of the subject, a critical questioning of historical-cultural products and their presentation (for example, on the basis of a film clip or a cartoon) is anticipated in relation to learning about ancient cultures.

\section{The concept of historical culture in history curricula}

Jörn Rüsen (1991) introduced the concept of historical culture in the 1990s to describe collective approaches to history. It can be understood as a 'response to the traditional hermeneutic approaches to history education' (Grever and Adriaansen, 2017: 74). At that time, a substantial increase in social interest in historical topics could be observed (Bergmann, 1993), which is why it is not surprising that the study of extra-curricular, non-academic history learning was regarded as more significant within history didactics (Mütter, 1998). According to Rüsen (2002: 3), historical culture is generally defined as the 'totality of discourses in which a society understands itself and its future by interpreting its past'. The connection between historical culture and individual historical consciousness is seen as controversial (Ziegler, 2017), whereby Schönemann's (2000) definition of historical culture as the social counterpart of historical consciousness is viewed critically. There is also a debate about whether school and academic pursuits count as historical culture. Hans-Jürgen Pandel (2013) rejects this, and characterises historical culture according to its life-world presence, event character and genre change. Types of historical culture are thus found in the widest variety in all our everyday lives, some of which we encounter only briefly. Countless historical-cultural products exist on the same historical topic, which also address different target groups (Pandel, 2013). In any case, as understood in Austrian curricula, products of historical culture are to be 
seen as non-academic forms of engagement with the past (for example, films, computer games and comics), for which the curricula use the term 'historical representations' ('Geschichtsdarstellungen') or 'representations' ('Darstellungen'). Thus, in addition to the source-based approach, the curricula are also committed to the critical approach to historical culture that is widespread in German-speaking countries, according to which students should learn to question critically any historical representations which they encounter in their daily lives (Barsch and Mathis, 2020). Although there is also research where products of historical culture can become a source, and differentiation at a high level is no longer so easy, the curricula focus on the fundamental difference between a historical source, which dates from the respective historical period, and interpretations of the past (historical representations), which were created later.

Concerning the importance of historical culture for historical learning, critical comments can be found in the literature on history didactics. Bodo von Borries (2008b) believes that some history culture products do not go beyond infotainment. In this regard, however, it must be taken into account that products of the entertainment industry, in particular, can arouse interest in historical topics (Kohler, 2016), and can have a more significant influence on the historical consciousness of young people than history lessons (Thünemann and Jansen, 2018; Sperl, 2018). As research has shown, children are already strongly influenced by history culture before beginning history lessons in high school (Becher and Gläser, 2015; Kühberger, 2020). Furthermore, it is argued that the consideration of popular history cultural products - such as comics, computer games and films - can even be favourable for competence-oriented history teaching, as the constructed character of the narration is easier for students to recognise, whereas textbook authors or exhibition curators, for example, try to present things as objectively as possible (Koller, 2013). The deconstruction skills that are also necessary in later life (Von Borries, 2008a; Heuer, 2011; Völkel, 2017) can thus easily be nurturend. Rox-Helmer (2006) advocates including more fictional elements in history lessons, so that students acquire the ability to analyse these historical representations critically. Donnelly (2018: 115) rightly speaks out clearly in favour of the systematic inclusion of historical culture in history lessons:

The teacher-centred historical narrative ... needs to be relegated if historical understanding is the aim of history education. In its stead, a more constructionist paradigm with an emphasis on historical inquiry seeks to give students experience in creating historical interpretation using their historical imaginations and a complex web of evaluation and synthesis skills.

The curricula for teaching history in Austria introduced in 2016 follow these basic considerations. Since the reform became known, the teacher training colleges have offered numerous further training courses on the new curricula and the theoretical approaches embedded in them. However, no accompanying research on the implementation of the curricula has been conducted. Therefore, there are no empirical findings so far on the extent to which teachers are familiar with the innovations, although there is agreement that they play a crucial role in implementing the reforms that are ordered. After a long time in which history didactics paid little attention to teachers (Hasberg, 2010), it is now widely accepted that they are central subjects who have great freedom in the design of their lessons (Münch, 2017b), and therefore that they are responsible for the structuring of history lessons (Schulz-Hageleit, 2014), and have a significant influence on learners' conceptions of history (Evans, 1990). As a result, the beliefs (Bernhard, 2019a; Nitsche, 2019), historical-didactic knowledge, teacher training and practical school experiences of history teachers have been researched in numerous projects in recent years (Maggioni et al., 2004; Popp et al., 2013; Waldis et al., 2014; Fenn, 2015; Schröer, 2015; Thünemann, 2016; Bernhard, 2017; Heuer et al., 2017; Litten, 2017; Ecker, 2018; Lüke et al., 2018; Nitsche, 2017; Resch and Seidenfuß, 2018; Heuer, 2019).

These studies have shown that teachers' actions are influenced by many different factors, including teacher training. However, this has changed considerably in recent decades, so that there are currently history teachers who are familiar with current didactic theories to very different extents. In one type of school for children between the ages of 10 and 14 ('Mittelschulen'), teachers teach history who have not studied the subject themselves. 
In what follows, it will be investigated: (1) to what extent history teachers working in Austrian middle and high schools are familiar with the concept of historical culture; (2) whether and how they take this into account when teaching history; and (3) to what extent it is important to them that their students learn how to deconstruct historical representations, as required by the FUER competence model and consequently by the curricula. This will contribute to the question, to what extent do history teachers have the historicaldidactic knowledge to be able to implement the curricula?

\section{Sample and methods}

The data on which the article is based were collected within the project Historical Learning Between School and Museum (for the results, see Brait, 2020), which mainly researched the embedding of museum visits in history lessons. However, the current alignment of 'regular' history lessons also played a role in this research project, which is why this was thematised in the interviews with history teachers $(n=85)$. The following explanations refer to these interviews. The identifiers for interviews include the type of school and the province. 'AHS' stands for the school type 'Allgemeinbildende höhere Schule' (attended by children between 10 and 18 years of age, in which general higher education is taught, and which ends with the university entrance examination). 'NMS' stands for 'Neue Mittelschulen' (compulsory school attended by children between 10 and 14 years of age). 'BHS' stands for 'Berufsbildende höhere Schulen' (this includes various school types that combine training for certain professions with general education, which end with the university entrance examination, and which are attended by children between 14 and 19 years of age). The provinces are indicated as follows: $\mathrm{Bgl}=$ Burgenland, Ktn $=$ Carinthia, NÖ = Lower Austria, OÖ = Upper Austria, Sbg = Salzburg, Stm = Styria, Tirol = Tyrol, Vbg = Vorarlberg, Wien = Vienna. For example, the interview AHS_Wien_1 is the first interview conducted at the AHS school type from Vienna.

In selecting the teachers, attention was paid to diversity to achieve theoretical saturation (Bogner et al., 2014). Therefore, history teachers from all Austrian provinces, from urban and rural regions and from different types of schools, as well as those with different seniorities, were interviewed. In addition, 'unexamined' teachers (who teach history, but who have not studied the subject) were part of the sample. Although attention was paid to covering as many aspects of the field as possible, it is not a representative sample, which is why no quantifying statements can be made in relation to the whole population of Austrian history teachers. The sampling can best be described as a snowball procedure (Krippendorff, 2019), combined with other sampling methods (Przyborski and Wohlrab-Sahr, 2014). The interviews were conducted between January 2018 and December 2019; the duration of the interviews was 56 minutes on average. The interviewed teachers are mentioned anonymously (only the federal state and the school type are identified).

The interviews were semi-structured, and aimed to elicit relatively free narratives from the interviewees by asking short questions (Gläser and Laudel, 2010); for example:

Please try to describe your teaching of history in general terms: what do you mainly want the pupils to learn?

To what extent do you include historical representations in your history lessons? Which ones? To what extent are pupils taught the difference between sources and historical representations? What do you think about competence orientation in general?

As far as possible, attention was paid to the wording, so that the interviewees could not conclude which answers were socially desirable. Therefore, questions were mainly asked about experiences and teaching practice, and a test of historical-didactic knowledge was avoided. For example, teachers were asked very openly what their goals were in history education, and what they thought students should ultimately be able to do. Active listening was consequently central to the interview process, and the personal views of the history teachers were not evaluated, even if they appeared problematic from the point of view of the project leader (Helfferich, 2011). This, of course, has the disadvantage that no quantifying conclusions 
are possible, as would be the case, for example, with highly structured interviews. However, the chosen approach allows a closer look at teachers' beliefs.

The analysis of the verbatim (but not phonetically) transcribed interviews (Stefer et al., 2007: 27-9) was carried out with content-structuring qualitative content analysis. However, as suggested by Thyroff (2020), quantification was not the aim, although classifying statements (in the sense of 'frequently', 'rarely' and so on) are made to complement the analysis of the findings. This method is suitable for all data material collected in communication situations (Barsch, 2016). It allows the identification of themes and sub-themes, their systematisation and the analysis of mutual relations among them (Kuckartz, 2018). The category system was developed mainly - although not exclusively (Ruona, 2005) - in an inductive way. This approach allows 'research findings to emerge from the frequent, dominant, or significant themes inherent in raw data, without the restraints imposed by structured methodologies' (Thomas, 2006: 238). Finally, the category system created in MAXODA was tested for intercoder reliability (Brennan and Prediger, 1981) using 12 per cent of the material (Lombard et al., 2002), which showed an acceptable average value of $\mathrm{K}_{\mathrm{n}}=0.79$.

\section{Findings and discussion}

\section{Lack of knowledge of historical-didactic terms}

First, it can be noted that only a few teachers mentioned historical representations of their own accord in the interviews when asked about the aims of history education. A teacher from Upper Austria was the only one who said that 'a critical approach to representations, to historical-cultural products' (AHS_OÖ_1) is a central goal of history education. Most of the other teachers did not mention individual forms of historical representations or the deconstruction of such concerning their teaching practice. To be able to analyse whether historical representations were taken into account in history lessons, the teachers were actively asked about this. The question about whether they take historical representations into account in their history lessons was asked of all 85 teachers, regardless of the questions about the curricula introduced in 2016, as work with manifestations of historical culture is relevant in all types of schools.

Regarding the question about the use of historical representations, it is noticeable that - compared with all other questions asked - there were some misunderstandings and many queries. For example, one teacher asked whether it meant that students drew something in history lessons (AHS_OÖ_2). Another teacher understood the term 'historical representations' as role play, and explained how a scene on the topic of 'selling of indulgences' was acted in her class (BHS_Ktn_1). A teacher from Tyrol thought that caricatures were meant (NMS_Tirol_5), while a teacher from Vienna was able to give at least one correct example after a query: 'Historical representations? You mean documentations, don't you?' (AHS_Wien_12).

The interviews revealed a clear lack of knowledge of the historical-didactic concept of historical culture and the relevant terms used in the curricula. Most of the history teachers interviewed first wanted to know what is meant by the term 'historical representations' and its use in history education before answering the question, as these examples show:

What do you mean by historical representations? (AHS_Wien_22)

What do you mean? (BHS_NÖ_1)

You now mean historical representations in the sense of ... (BHS_Tirol_2)

What do you mean exactly? I have to ask what you mean exactly. (BHS_Wien_4)

What do you mean? (NMS_OÖ_1)

However, as the following passage from an interview shows, the teachers interviewed do use some historical representations in their history lessons, even if they do not know the term:

Interviewer: Do you also use historical representations in your lessons?

AHS_Stm_3: What do you mean?

Interviewer: For example, movies or documentaries? 
AHS_Stm_3: OK, yes. Basically ... I start, at least thematically, I always like to watch short videos on whatever, as an intro mainly, but also in between, I always like to watch short sequences, yes. I work at the end of the semester ... there is usually some film that fits the topic, or otherwise I also like to work with videos that I usually ... I usually watch them in advance and with which you can get started and also discuss well.

The teacher's statements suggest that filmic representations are often shown in lessons, although it is not clear whether they are dramas or documentaries. In any case, the term 'watch' does not indicate a criterion-led analysis or deconstruction of the historical representations. As has been shown, teachers do not understand the term 'historical representations', which is used in the curricula. Furthermore, they do not encourage their students to engage critically with historical representations, as will be shown in the next section.

\section{Watching instead of deconstructing}

As in the example above, when historical representations are used in history lessons, this is not automatically connected with critical analysis. Another example is a teacher from Vienna, who complained in the interview that source work in class is problematic because sources are 'not tangible for the children'. Subsequently, the interviewer asked whether representations work better, whereupon the teacher, after a short explanation of the meaning of the term using examples by the interviewer, stated:

This is a generation that has grown up with television, with documentaries with these things. When they watch that, they realise more.... Yes, but you know, what I have also noticed, funnily enough, is that there are individual internet games where historical facts are present, and sometimes you are astonished what they got from somewhere and know from somewhere. They get that from these games and therefore edutainment, yes. I do believe that this is one way, but as you say, as a scientist, you have to be very critical with sources, and I wonder if this is the case among the game developers, if there is a scientific advisory board there. But that would be very desirable. So you could actually get historical facts ... Honestly, that would be the salvation par excellence. That's my opinion. (BHS_Wien_6)

Asked if the learners can distinguish between primary sources and historical representations, this teacher replies unequivocally: 'No, they can't do that' (BHS_Wien_6). From this insight, however, this teacher does not derive a mandate for history education to teach students basic deconstruction skills, but advocates that the historical representations consumed by young people should contain 'historical facts'.

Furthermore, it should be noted that, obviously, not all Austrian history teachers are familiar with historical representations and their analysis. For example, when asked whether the difference between primary sources and historical representations is understood by the students, one teacher explains: 'I sometimes have problems myself' (NMS_Wien_3). As another teacher states, the didactic preparation for lessons causes difficulties, which is why this teacher refrains from using historical representations (BHS_Wien_8). A teacher from Tyrol argues that this should only be taught in the higher classes, and that the lessons in the lower classes should be more 'playful' (AHS_Tirol_2). Another teacher also assumes that the difference is difficult for children to understand: 'I don't know if they are really aware of it. So I try to explain that it wasn't really like that in the feature film, but I think it's just very difficult for that age group' (NMS_OÖ_1). The deconstruction demanded in the curricula is thus not a central goal of history education for most of the teachers interviewed, although historical representations are not completely ignored in the classroom, as will be shown in the next section.

\section{The limited range of historical representations used by teachers}

Only a few history teachers in the sample consider the deconstruction of historical representations to be generally important: One teacher, for example, states that he/she deals with many different historical 
representations in history lessons, and likes to discuss with the students that it is not always possible to clearly distinguish between sources and historical representations (AHS_Tirol_5). So these students clearly understood that the answer to the question 'What is a source?' depends upon the research question. Another teacher talks about the use of different forms of historical representation and analysing the aesthetics of images in films with students (BHS_Wien_3). On the other hand, one teacher from Tyrol finds it particularly important to point out fictional elements in feature films. (NMS_Tirol_4). A teacher from Lower Austria also explains: 'You have to tell them that quite clearly right from the beginning. Because this awareness, this is a feature film and this is reality' (BHS_NÖ_5).

Overall, it is noticeable that - similar to Donnelly's (2018) findings - films and documentaries are mentioned in particular. However, in the case of films, many teachers emphasise that entire films are rarely, if ever, shown. A teacher from Vienna, like many other respondents, argues that there is not enough time for this (AHS_Wien_10). Another teacher claims to have time for historical representations only when a part of them can be viewed in another subject lesson (BHS_NÖ_4).

Other manifestations of historical culture, such as historical novels, comics or computer games, play a subordinate role in the teachers' interviews. One teacher explains openly that he/she has no knowledge about this (NMS_Wien_2). Another teacher also explains, 'Yes, but I simply have to say that I am far too unskilled in dealing with the media' (AHS_Wien_11). A teacher from Vienna rejects computer games on principle because 'they are mostly nonsense' (AHS_Wien_12). Another teacher explains in the interview that she/he knows that the analysis of a comic is obligatory in the curriculum and that she/he has tried it. However, she/he was 'completely overwhelmed' with it, as she/he did not know why this had to be taught (AHS_Wien_6).

\section{Verification of other studies}

These results correspond with other relevant research. Textbook analyses, for example, show that the deconstruction of historical representations, such as the author's text, is certainly not commonplace in Austrian history education (Kipman and Kühberger, 2019). Pichler's (2020) study of final examinations at the end of senior high school revealed a general ignorance of the genre-specific characteristics of the different types of historical sources and representations; sources were recognised in single cases, but representations were hardly noticed. This leads to the assumption that these were not discussed in depth in history education. Studies in Germany also suggest that history teachers do not consider it an essential goal of history education to teach the deconstruction of historical representations (Von Borries, 2005). Some teachers also seem to be barely familiar with the concept of historical culture. For example, respondents in Münch's (2017a) quantitative survey named different source categories, such as diaries and autobiographies, when asked for examples of historical culture, although this was defined in detail as 'dealing with history in public'. With regard to the integration of historical culture into their history education, the teachers that Münch (2017a) interviewed saw problems due to a lack of time and the financial and organisational effort involved.

\section{Summary and implications for politics and history didactics}

The interviews clearly showed that the history teachers working in Austria's high schools are in most cases unfamiliar with the concept of historical culture. Many teachers interviewed do not even know the term 'historical representation', although it is frequently mentioned in the curricula from 2016 . Some manifestations of historical culture are, nevertheless, used in history lessons, according to the teachers interviewed. In particular, films and documentaries were mentioned by many interviewees, while other forms of historical representations, such as computer games or historical novels, are almost ignored. Furthermore, the historical representations that were used were hardly ever critically questioned. 
Most of the teachers interviewed do not know that students should learn to deconstruct historical representations.

The state-defined teaching contents are thus not implemented by many teachers in the sample, although assistance can already be found in all state-approved textbooks. Consequently, the competence goals formulated in the curricula cannot be achieved. Since the teachers do not pay particular attention to fostering students' deconstruction competence, which is anchored in the FUER competence model, and consequently in the curricula, the students are not adequately prepared for the everyday handling of historical culture in their later lives.

In order to achieve a change in current teaching practice, educational policy and academic history didactics are equally required. Policy is responsible for the sufficient training and further education of teachers. Given that it has been empirically proven that knowledge of the theoretical foundations of the current curricula is not disseminated widely enough, additional training for history teachers should no longer be voluntary, but mandatory. This would also be of benefit to history teachers, who are obviously in part not even able to fully understand the terms and theories used in the curricula, as the interviews clearly show.

In recent decades, German-language history didactics has been especially preoccupied with further developing theories and empirical research. In that process, questions of teaching practice have often been given too little attention. To prevent the much-lamented gap between academic history didactics and teaching practice from widening further, it is necessary that history didactics gives more consideration to the implementation of theories, and the development and publication of teaching examples.

However, in order to ensure that the new proposals for teaching are utilised, it is crucial that teachers get more involved in their development, for example through workshops and cooperation between universities and schools. In this way, the views and experiences of those who are actually in the classroom every day can receive the same consideration as the theories of history didactics.

\section{Acknowledgements and funding}

The author thanks Jasmin Fischer, Nina Hechenblaikner and Laura Volgger, who transcribed the interviews, and who were employed for this purpose by the University of Innsbruck. Funding was provided by the university and through two sub-projects (Zukunftsfonds der Republik Österreich: Förderung eines reflexiven Geschichts- und Demokratiebewusstseins durch Museumsbesuche im Geschichtsunterricht; University of Innsbruck: Teilautomatisierte Transkription von Experteninterviews in österreichischem Deutsch). Further transcriptions were privately financed by the author.

\section{Declarations and conflicts of interest}

\section{Research ethics statement}

The author conducted the research reported in this article in accordance with the standards of the Directorates of Education in Austria.

\section{Consent for publication statement}

The author declares that research participants' informed consent to publication of findings - including photos, videos and any personal or identifiable information - was secured prior to publication.

\section{Conflicts of interest statement}

The author declares no conflicts of interest with this work. All efforts to sufficiently anonymise the author during peer review of this article have been made. The author declares no further conflicts with this article. 


\section{References}

Ammerer, H. (2009) 'Zur Situation der Politischen Bildung in Österreich'. In H. Ammerer, R. Krammer, C. Kühberger and E. Windischbauer (eds), Politische Bildung konkret: Beispiele für kompetenzorientierten Unterricht. Vienna: Ed. Polis, 2-4.

Barsch, S. (2016) 'Die Qualitative Inhaltsanalyse als Methode der geschichtsdidaktischen Forschung'. In H. Thünemann and M. Zülsdorf-Kersting (eds), Methoden geschichtsdidaktischer Unterrichtsforschung. Schwalbach/Ts: Wochenschau, 206-28.

Barsch, S. and Mathis, C. (2020) " With these exhibits many interesting things can be learned about past times": Playmobil's History Class - representations, reflections and expectations'. History Education Research Journal, 17 (2), 151-63. http://doi.org/10.14324/HERJ.17.2.02.

Becher, A. and Gläser, E. (2015) 'Historisches Denken und Kompetenzentwicklung im Elementar- und Primarbereich (HisDeKo) - Ein Projektbericht'. In M. Waldis and B. Ziegler (eds), Forschungswerkstatt Geschichtsdidaktik 13: Beiträge zur Tagung geschichtsdidaktik empirisch 13. Bern: hep der Bildungsverlag, 41-51.

Bergmann, K. (1993) "'So viel Geschichte wie heute war nie" - Historische Bildung angesichts der Allgegenwart der Geschichte'. In A. Schwarz (ed.), Politische Sozialisation und Geschichte: Festschrift für Rolf Schörken zum 65. Geburtstag. Hagen: Rottmann, 209-28.

Bernhard, R. (2016) 'Lernaufgaben zur Förderung historischer Denkprozesse: Normative Richtlinien für Geschichtsschulbücher und deren Implementierung in Österreich'. In E. Matthes and S. Schütze (eds), Schulbücher auf dem Prüfstand: Textbooks under scrutiny. Bad Heilbrunn: Verlag Julius Klinkhardt, 31-40.

Bernhard, R. (2017) 'Are historical thinking skills important to history teachers? Some findings from a qualitative interview study in Austria'. International Journal of Historical Learning, Teaching and Research, 14 (2), 29-39. Accessed 16 December 2021. https://www.history.org.uk/secondary/categories/380/resource/9187/are-historical-thinking-skillsimportant-to-histor.

Bernhard, R. (2019a) 'Berufsbezogene Überzeugungen österreichischer Geschichtslehrpersonen und historisches Denken'. Habilitation thesis, University of Salzburg.

Bernhard, R. (2019b) 'Using mixed methods to capture complexity in an empirical project about teachers' beliefs and history education in Austria'. History Education Research Journal, 16 (1), 63-73. http://doi.org/10.18546/HERJ.16.1.06.

BGBI. (Bundesgesetzblatt für die Republik Österreich) (2008) Änderung der Verordnungen über die Lehrpläne der Volksschule, der Sonderschulen, der Hauptschulen und der allgemein bildenden höheren Schulen (BGBI. II 290/2008). Accessed 20 December 2021. https://www.ris.bka.gv.at/Dokumente/Bgb|Auth/BGBLA_2008_II_290/BGBLA_2008_ II_290.pdfsig.

BGBI. (Bundesgesetzblatt für die Republik Österreich) (2016a) Änderung der Verordnung über die Lehrpläne der Hauptschulen, der Verordnung über die Lehrpläne der Neuen Mittelschulen sowie der Verordnung über die Lehrpläne der allgemein bildenden höheren Schulen (BGBI. II 113/2016). Accessed 20 December 2021. https://www.ris.bka.gv.at/ Dokumente/Bgb|Auth/BGBLA_2016_II113/BGBLA_2016_II_113.pdfsig.

BGBI. (Bundesgesetzblatt für die Republik Österreich) (2016b) Änderung der Verordnung über die Lehrpläne der allgemein bildenden höheren Schulen; Änderung der Bekanntmachung der Lehrpläne für den Religionsunterricht an diesen Schulen (BGBI. II 219/2016). Accessed 20 December 2021. https://www.ris.bka.gv.at/Dokumente/BgblAuth/ BGBLA_2016_II219/BGBLA_2016_II219.pdfsig.

Bogner, A., Littig, B. and Menz, W. (2014) Interviews mit Experten: Eine praxisorientierte Einführung. Wiesbaden: Springer.

Bozkurt, D., Brinek, G. and Retzl, M. (2007) 'PISA in Österreich: Mediale Reaktionen, öffentliche Bewertungen und politische Konsequenzen'. In S. Hopmann (ed.), PISA zufolge PISA: PISA according to PISA; hält PISA, was es verspricht? Vienna: LIT, 321-62.

Brait, A. (2020) 'Museumsbesuche im Geschichtsunterricht: Eine Studie zum historischen Lernen im Zuge von Besuchen der österreichischen Landesmuseen'. Habilitation thesis, University of Innsbruck.

Bramann, C. (2019) 'Arbeitsaufträge und Kompetenzen: Geschichtsschulbücher im Kontext einer fachspezifischen Aufgabenkultur'. In C. Kühberger, R. Bernhard and C. Bramann (eds), Das Geschichtsschulbuch: Lehren - Lernen Forschen. Münster: Waxmann, 161-84.

Brennan, R.L. and Prediger, D.J. (1981) 'Coefficient kappa: Some uses, misuses, and alternatives'. Educational and Psychological Measurement, 41 (3), 687-99. https://doi.org/10.1177\%2F001316448104100307.

Buchberger, W. (2020) Historisches Lernen mit schriftlichen Quellen: Eine kategoriale Schulbuchanalyse österreichischer Lehrwerke der Primar- und Sekundarstufe. Innsbruck: StudienVerlag.

Donnelly, D.J. (2018) 'Contemporary multi-modal historical representations and the teaching of disciplinary understandings in history'. Journal of International Social Studies, 8 (1), 113-32. Accessed 16 December 2021. https:// files.eric.ed.gov/fulltext/EJ1173479.pdf.

Ecker, A. (2018) 'The education of history teachers in Europe - a comparative study: First results of the "Civic and History Education Study"'. Creative Education, 9 (10), 1565-1610. https://doi.org/10.4236/ce.2018.910115.

Eder, F. and Thonhauser, J. (2017) 'Österreich'. In H. Döbert, W. Hörner, B. von Kopp and L. R. Reuter (eds), Die Bildungssysteme Europas. Baltmannsweiler: Schneider-Verl. Hohengehren, 536-58. 
Eigler, N. and Kühberger, C. (2018) 'Zur kompetenzorientierten Einbindung von Bildern in Geschichtsschulbüchern: Eine geschichtsdidaktisch kategoriale Erschließung am Beispiel des Themenbereiches Nationalsozialismus und Holocaust'. In C. Bramann, C. Kühberger and R. Bernhard (eds), Historisch Denken lernen mit Schulbüchern. Frankfurt am Main: Wochenschau, 160-80.

Evans, R.W. (1990) 'Teacher conceptions of history revisited: Ideology, curriculum, and student belief'. Theory \& Research in Social Education, 18 (1), 101-38. https://doi.org/10.1080/00933104.1990.10505608.

Fenn, M. (2015) 'Beeinflusst geschichtsdidaktische Lehre die subjektiven Theorien von Studierenden?: Ergebnisse einer empirischen Interventionsstudie'. Geschichte in Wissenschaft und Unterricht, 66 (9/10), 515-38. Accessed 16 December 2021. https://www.fachportal-paedagogik.de/literatur/vollanzeige.html?Fld=1085062.

Germ, A. (2015) Konzeptuelles Lernen in der politischen Bildung: Theoriebildung - Fachdidaktische Umsetzung Praxisbeispiele. Vienna: LIT.

Gläser, J. and Laudel, G. (2010) Experteninterviews und qualitative Inhaltsanalyse als Instrumente rekonstruierender Untersuchungen. Wiesbaden: VS.

Grever, M. and Adriaansen, R.-J. (2017) 'Historical culture: A concept revisited'. In M. Carretero, S. Berger and M. Grever (eds), Palgrave Handbook of Research in Historical Culture and Education. London: Palgrave Macmillan, 73-89.

Hacker, H. (1999) 'Lehrplan'. In D. Lenzen (ed.), Pädagogische Grundbegriffe: Band 2. Reinbeck bei Hamburg: Rowohlt, 972-7.

Hasberg, W. (2010) 'Historiker oder Pädagoge?: Geschichtslehrer im Kreuzfeuer der Kompetenzdebatte'. Zeitschrift für Geschichtsdidaktik, 9, 159-79. https://doi.org/10.13109/zfgd.2010.09.1.159.

Helfferich, C. (2011) Die Qualität qualitativer Daten: Manual für die Durchführung qualitativer Interviews. Wiesbaden: VS Verl. für Sozialwiss.

Heuer, C. (2011) 'Historisches Lernen vor Ort - Skizze für ein zeitgenössisches Bild vom ausserschulischen historischen Lernen'. In K. Messmer, R. von Niederhäusern, A. Rempfler and M. Wilhelm (eds), Ausserschulische LernortePositionen aus Geographie, Geschichte und Naturwissenschaften. Zürich: LIT, 50-81.

Heuer, C. (2019) '"Does the teacher matter?": Questions about the unknown perspectives from German-language history didactics'. International Journal of Research on History Didactics, History Education and History Culture, 40, 201-16. Accessed 16 December 2021. https://jhec.wochenschau-verlag.de/wp-content/uploads/sites/23/2021/05/ issue_2019.pdf\#page=202.

Heuer, C., Resch, M. and Seidenfuß, M. (2017) 'Geschichtslehrerkompetenzen? Wissen und Können geschichtsdidaktisch'. Zeitschrift für Didaktik der Gesellschaftswissenschaften, 8 (2), 158-76. Accessed 16 December 2021. https://elibrary. utb.de/doi/abs/10.46499/979.1237.

Kipman, U. and Kühberger, C. (2019) Einsatz und Nutzung des Geschichtsschulbuches: Eine Large-Scale-Untersuchung bei Schülern und Lehrern. Wiesbaden: Springer.

Kohler, C. (2016) Schülervorstellungen über die Präsentation von Geschichte im Museum: Eine empirische Studie zum historischen Lernen im Museum. Berlin: LIT.

Koller, J. (2013) 'Geschichte wozu?: Außerschulische Geschichtskultur als Baustein eines kompetenzorientierten Geschichtsunterrichts'. In P. Ehrenpreis and J. Koller (eds), Geschichte ist überall: Geschichtsunterricht und außerschulische Geschichtskultur: Überblick, Impulse, Materialien. Bamberg: C.C. Buchners, 10-22.

Körber, A., Schreiber, W. and Schöner, A. (eds) (2007) Kompetenzen historischen Denkens: Ein Strukturmodell als Beitrag zur Kompetenzorientierung in der Geschichtsdidaktik. Neuried: Ars Una.

Krippendorff, K. (2019) Content Analysis: An introduction to its methodology. Los Angeles: Sage.

Kuckartz, U. (2018) Qualitative Inhaltsanalyse: Methoden, Praxis, Computerunterstützung. Weinheim: Beltz Juventa.

Kühberger, C. (2012) 'Konzeptionelles Wissen als besondere Grundlage des historischen Lernens'. In C. Kühberger (ed.), Historisches Wissen: Geschichtsdidaktische Erkundung zu Art, Tiefe und Umfang für das historische Lernen. Schwalbach/Ts: Wochenschau-Verl., 33-74.

Kühberger, C. (2020) 'Informelles Lernen mit Spielzeug? Ethnographische Beobachtungen zu Geschichtsdarstellungen im Kinderzimmer'. In S. Barsch and J. van Norden (eds), Historisches Lernen und Materielle Kultur: Von Dingen und Objekten in der Geschichtsdidaktik. Bielefeld: transcript, 111-24.

Litten, K. (2017) Wie planen Geschichtslehrkräfte ihren Unterricht? Eine empirische Untersuchung der Unterrichtsvorbereitung von Geschichtslehrpersonen an Gymnasien und Hauptschulen. Göttingen: Vandenhoeck \& Ruprecht.

Lombard, M., Snyder-Duch, J. and Bracken, C.C. (2002) 'Content analysis in mass communication: Assessment and reporting of intercoder reliability'. Human Communication Research, 28 (4), 587-604. https://doi. org/10.1111/j.1468-2958.2002.tb00826.x.

Lucyshyn, J. (2013) 'Das schiefe Ergebnis von PISA \& Co: Über den schiefen Umgang Österreichs mit Schulleistungstests'. Österreichisches Jahrbuch für Politik, 377-90.

Lüke, N., Seider, J. and Fenn, M. (2018) 'Struktur und Inhalt des fachbezogenen Professionswissens angehender Lehrkräfte in den Geisteswissenschaften'. heiEDUCATION Journal, 1 (1-2), 75-98. https://doi.org/10.17885/heiup. heied.2018.1-2.23827. 
Maggioni, L., Alexander, P. and VanSledright, B. (2004) 'At a crossroads? The development of epistemological beliefs and historical thinking'. European Journal of School Psychology, 19 (2), 169-97. Accessed 16 December 2021. https:// www.researchgate.net/publication/271429277_At_a_crossroads_The_development_of_epistemological_beliefs_and_ historical_thinking.

Mittnik, P. (2014) 'Zentrale Themen des Geschichtsunterrichts in Österreich: Analyse der Reifeprüfungsaufgaben am Wiener AHS aus dem Fach Geschichte und Sozialkunde/Politische Bildung. Eine empirische Erhebung'. Historische Sozialkunde, 44 (4), 26-37. Accessed 16 December 2021. https://fdzgeschichte.univie.ac.at/fileadmin/user_upload/i_ fdzgeschichte/Unterricht/HSK_Hefte/4_2014.pdf.

Mittnik, P. (2018) 'Nationalsozialismus im Schulbuch: Geschichtsdidaktische Zugänge in deutschen, österreichischen und englischen Lehrwerken der Sekundarstufe I'. In C. Bramann, C. Kühberger and R. Bernhard (eds), Historisch Denken lernen mit Schulbüchern. Frankfurt am Main: Wochenschau, 111-35.

Münch, D. (2017a) 'Geschichtskultur als Thema des Geschichtsunterrichts: Wie stehen Lehrkräfte zu dieser Idee?'. In U. Danker (ed.), Geschichtsunterricht - Geschichtsschulbücher - Geschichtskultur: Aktuelle geschichtsdidaktische Forschungen des wissenschaftlichen Nachwuchses. Göttingen: V\&R Unipress, 179-95.

Münch, D. (2017b) 'Geschichtskultur im Geschichtsunterricht - Deutungen reflektieren oder Inhalte vermitteln?'. Zeitschrift für Geschichtsdidaktik, 16, 167-82. https://doi.org/10.13109/zfgd.2017.16.1.167.

Mütter, B. (1998) '"Geschichtskultur" - Zukunftsperspektive für den Geschichtsunterricht am Gymnasium'. Geschichte, Politik und ihre Didaktik, 26 (3/4), 165-77.

Nitsche, M. (2017) 'Geschichtstheoretische und -didaktische Beliefs angehender und erfahrener Lehrpersonen - Einblicke in den Forschungsstand, die Entwicklung der Erhebungsinstrumente und erste Ergebnisse'. In U. Danker (ed.), Geschichtsunterricht - Geschichtsschulbücher - Geschichtskultur: Aktuelle geschichtsdidaktische Forschungen des wissenschaftlichen Nachwuchses. Göttingen: V\&R Unipress, 85-106.

Nitsche, M. (2019) Beliefs von Geschichtslehrpersonen - eine Triangulationsstudie. Bern: hep verlag ag.

Oberhauser, C. (2018) " "[l]ch sehe, dass es mehr mit dem zu tun hat, was Geschichte eigentlich ist": Tiroler Gymnasiallehrpersonen im Fach Geschichte und Sozialkunde/ Politische Bildung und ihre Einstellung zur Neuen Mündlichen Reifeprüfung'. In W. Schreiber, B. Ziegler and C. Kühberger (eds), Geschichtsdidaktischer Zwischenhalt: Beiträge aus der Tagung "Kompetent machen für ein Leben in, mit und durch Geschichte" in Eichstätt vom November 2017. Münster: Waxmann, 317-22.

Pandel, H.-J. (2013) Geschichtsdidaktik: Eine Theorie für die Praxis. Schwalbach/Ts. Wochenschau.

Pichler, C. (2016) 'Kompetenzorientierter Geschichtsunterricht und fachspezifisches Professionsverständnis, ein Dilemma'. Zeitschrift für Didaktik der Gesellschaftswissenschaften, 7 (2), 13-31.

Pichler, C. (2020) Geschichtsmatura: Eine empirische Untersuchung zum kompetenzorientierten Prüfungsmodus. Innsbruck: Studienverl.

Popp, S. (2008) 'National textbook controversies in a globalizing world'. Yearbook. International Society for the Didactics of History, 109-22. Accessed 16 December 2021. https://www.researchgate.net/publication/328184388_National_ Textbook_Controversies_in_a_Globalizing_World.

Popp, S., Sauer, M., Alavi, B., Demantowsky, M. and Kenkmann, A. (eds) (2013) Zur Professionalisierung von Geschichtslehrerinnen und Geschichtslehrern: Nationale und internationale Perspektiven. Göttingen: V\&R Unipress.

Przyborski, A. and Wohlrab-Sahr, M. (2014) Qualitative Sozialforschung: Ein Arbeitsbuch. Munich: Oldenbourg.

Resch, M. and Seidenfuß, M. (2018) 'Fachdidaktische Kompetenzen angehender Geschichtslehrkräfte beim Formulieren von Lernaufgaben: Theoretische Beschreibung und empirische Erfassung mit einem Vignettentest'. In J. Rutsch, M. Rehm, M. Vogel, M. Seidenfuß and T. Dörfler (eds), Effektive Kompetenzdiagnose in der Lehrerbildung: Professionalisierungsprozesse angehender Lehrkräfte untersuchen. Wiesbaden: Springer Fachmedien Wiesbaden, 115-28.

Rox-Helmer, M. (2006) Jugendbücher im Geschichtsunterricht. Schwalbach/Ts. Wochenschau-Verl.

Ruona, W.E.A. (2005) 'Analyzing Qualitative Data'. In R.A. Swanson and E.F. Holton (eds), Research in Organizations: Foundations and methods in inquiry. San Francisco: Berrett-Koehler, 233-63.

Rüsen, J. (1991) 'Geschichtsdidaktik heute - Was ist und zu welchem Ende betreiben wir sie (noch)?'. In E. Hinrichs, W. Jacobmeyer and K.-E. Jeismann (eds), Bildungsgeschichte und historisches Lernen. Frankfurt am Main: Diesterweg, 9-23.

Rüsen, J. (2002) Geschichte im Kulturprozess. Cologne: Böhlau.

Schönemann, B. (2000) 'Geschichtsdidaktik und Geschichtskultur'. In B. Mütter, B. Schönemann and U. Uffelmann (eds), Geschichtskultur: Theorie - Empirie - Pragmatik. Weinheim: Deutscher Studien, 26-58.

Schröer, L. (2015) Individuelle didaktische Theorien und Professionswissen: Subjektive Konzepte gelingenden Geschichtsunterrichts während der schulpraktischen Ausbildung. Berlin: LIT.

Schulz-Hageleit, P. (2014) Alternativen in der historisch-politischen Bildung: Mainstream der Geschichte: Erkundungen Kritik - Unterricht. Schwalbach/Ts. Wochenschau-Verl.

Sperl, A. (2018) 'Der Einfluss von Medien auf das Österreichbild Jugendlicher'. In A. Ecker and A. Sperl (eds), Österreichbilder von Jugendlichen: Zum Einfluss audiovisueller Medien. Vienna: New Academic Press, 127-39. 
Stefer, C., Rädiker, S., Dresing, T. and Kuckartz, U. (2007) Qualitative Evaluation: Der Einstieg in die Praxis. Wiesbaden: VS.

Thomas, D.R. (2006) 'A general inductive approach for analyzing qualitative evaluation data'. American Journal of Evaluation, 27 (2), 237-46. https://doi.org/10.1177\%2F1098214005283748.

Thünemann, H. (2016) '“Ganz, ganz historisch gedacht”: Merkmale guten Geschichtsunterrichts aus Lehrerperspektive'. In J. Meyer-Hamme, H. Thünemann and M. Zülsdorf-Kersting (eds), Was heißt guter Geschichtsunterricht? Perspektiven im Vergleich. Schwalbach/Ts.: Wochenschau, 41-56.

Thünemann, H. and Jansen, J. (2018) 'Historisches Denken lernen'. In S. Bracke, C. Flaving, J. Jansen, M. Köster, J. Lahmer-Gebauer, S. Lankes, C. Spieß, H. Thünemann, C. Wilfert and M. Zülsdorf-Kersting (eds), Theorie des Geschichtsunterrichts. Frankfurt am Main: Wochenschau, 71-106.

Thyroff, J. (2020) Aneignen in einer historischen Ausstellung: Eine Bestandsaufnahme von Elementen historischen Denkens bei Besuchenden der Ausstellung '14/18. Die Schweiz und der Grosse Krieg'. Bern: hep.

Völkel, B. (2017) Inklusive Geschichtsdidaktik: Vom inneren Zeitbewusstsein zur dialogischen Geschichte. Schwalbach/Ts.: Wochenschau Wissenschaft.

Von Borries, B. (2005) 'Lehrerbefragung zu Funktion und Qualität von Richtlinien'. In B. von Borries, C. Fischer, S. Leutner-Ramme and J. Meyer-Hamme (eds), Schulbuchverständnis, Richtlinienbenutzung und Reflexionsprozesse im Geschichtsunterricht: Eine qualitativ-quantitative Schüler- und Lehrerbefragung in Deutschsprachigen Bildungswesen 2002. Neuried: Ars Una, 233-53.

Von Borries, B. (2008a) Historisch denken lernen: Welterschließung statt Epochenüberblick. Geschichte als Unterrichtsfach und Bildungsaufgabe. Opladen: Budrich.

Von Borries, B. (2008b) '“Orte" des Geschichtslernens - Trivialität oder Schlüsselproblem'. In S. Handro and B. Schönemann (eds), Orte historischen Lernens. Berlin: Lit-Verl., 11-35.

Waldis, M., Nitsche, M., Marti, P., Hodel, J. and Wyss, C. (2014) '"Der Unterricht wird fachlich korrekt geleitet" - theoretische Grundlagen, Entwicklung der Instrumente und empirische Erkundungen zur videobasierten Unterrichtsreflexion angehender Geschichtslehrpersonen'. Zeitschrift für Geschichtsdidaktik, 13, 32-49. https://doi. org/10.13109/zfgd.2014.13.1.32.

Weinert, F.E. (2001) 'Vergleichende Leistungsmessung in Schulen - eine umstrittene Selbstverständlichkeit'. In F.E. Weinert (ed.), Leistungsmessungen in Schulen. Weinheim: Beltz, 17-31.

Wiater, W. (2009) 'Lehrplan, Curriculum, Bildungsstandards'. In K.-H. Arnold, U. Sandfuchs and J. Wiechmann (eds), Handbuch Unterricht. Bad Heilbrunn: Klinkhardt, 127-33.

Zeilner, F. (2011) Geschichte der Politischen Bildung in Österreich als Unterrichtsprinzip und als Unterrichtsfach. Frankfurt am Main: Peter Lang.

Ziegler, B. (2017) 'Einleitung'. Zeitschrift für Geschichtsdidaktik, 16, 5-16. https://doi.org/10.1007/978-3-658-18933-4_1. 